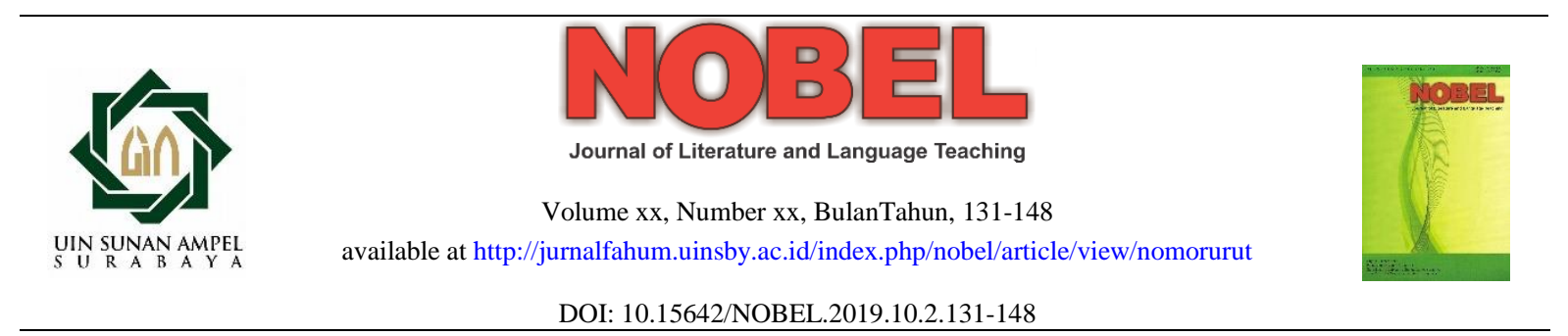

\title{
REPRESENTATION OF POWER IN THE NEWS TEXT OF THE INCLUSION OF INDIGENOUS FAITHS ON ID CARD (E-KTP)
}

\section{Faizal Risdianto $^{1 凶}$, Sumarlam $^{2}$, Riyadi Santosa $^{3}$}

IAIN Salatiga $^{1}$, Jl. Lingkar Salatiga KM 02, Pulutan, Sidorejo, Salatiga

Universitas Sebelas Maret ${ }^{2}$, Jl. Ir. Sutami No. 36 A Kentingan, Jebres, Surakarta

Universitas Sebelas Maret ${ }^{3}$, Jl. Ir. Sutami No. 36 A Kentingan, Jebres, Surakarta

\begin{tabular}{l}
\hline Article Info \\
\hline Article History: \\
Received June 2019 \\
Accepted August 2019 \\
Published September 2019 \\
\hline Keywords: \\
presentation of power, \\
Indigenous faiths, MUI, E- \\
KTP \\
\hline
\end{tabular}

\section{Abstract}

This paper presents the results of news analysis of the Supreme Court decision that Indigenous Faiths on the ID card (E-KTP) with Norman Fairclough's critical discourse analysis approach as the central platform. The study covers descriptions (text analysis), interpretations (discourse practices), and explanations (social practices). The results are as follows. (1) The structure of the news text Indigenous Faiths allowed on the ID card is built by four units of discourse: headline, orientation, the sequence of events, closing. Modalities and affirmative sentences represent the positive ideology of the conflicting faction and the institutions (government, scientists, and community leaders). Meanwhile, prohibiting speech and negative sentences represent the negative ideology. (2) What events occur, who is involved, what is the relationship with the issue raised, and what role the language can be expressed through the interpretation of the practice of discourse. (3) The situation when the news text is produced, the influence of the institution on the produced text, and the condition of Indonesians related to economic, political, social, and cultural interests (socio-cultural context). 


\section{INTRODUCTION}

Supreme Court decision about Indigenous Faiths (IF) on the ID card (E-KTP) is an interesting issue since Indonesia is a vulnerable country to racial problems. The followers of IF often get difficulties in getting jobs, getting married, and so on. It took 41 years for followers of IF to succeed in getting a Supreme Court decision related to the inclusion of IF on the ID card (E-KTP).

Regarding the Supreme Court's decision, the Indonesian Ulama Council (MUI) together with Community Organizations (CSOs) rejected the inclusion of IF allowed on the ID card (E-KTP). The Chairman of the MUI, Muhyiddin Junaidi, stated that IF was not a religion, so it was questioned why it was included in the religion column one-KTP (25/2/2019, poskotanews.com). Muhyiddin said that in IF there were various other factions or beliefs such as Sunda Wiwitan and others. Muhyiddin's concern is about their demand for the high position of such as director-general in the Indonesian Ministry of Religion after the government recognition for IF existence. This case was similar to Confucianism recognized as a religion. There is now a position that takes care of that religion in the Ministry of Religion.

The Director-General of Civil Registration of the Ministry of Home Affairs (Dukcapil Kemendagri), Prof. Zudan Arif Fakrulloh, confirmed that it had issued e-KTP with the column for IF. However, the inclusion of IF in e-KTP will not eliminate the existing recognized religions in Indonesia like Islam, Catholic, Christian, Budha, Hindu, and Konghucu. Zudan stated that what occurred was that the state acknowledged the existence of IF. He stressed the state's recognition of the IF was not the first time. In its resolution, the Constitutional Court granted applicants' requests from IF, related to the inclusion of IF in population documents, including e-KTP and KK (Family Card).

It is very interesting to study how the representation of power at Supreme Court decision that IF allowed on the ID card (E-KTP) and how is the solution to the problem? Who involved the discourse participated in IF inclusion on the ID card (E-KTP) and how was the case resolved? The above question becomes significant concerning the social reality that occurs in the community. In this case, Critical Discourse Analysis (CDA) can help 'solve the problem' from discourse analysis, text analysis, discourse practice, and socio-cultural practices. For this reason, in the author's view, the appropriate CDA approach to discussing this issue is Fairclough's Critical Discourse Analysis (CDA) (1995). 


\section{REVIEW OF LITERATURE}

\section{Characteristics of the Fairclough Model of CDA Approach}

Fairclough's CDA approach assumes that language becomes an inseparable part of social life, interconnected with other elements in social life, so discourse analysis must also have the concern to the issues outside of language. Discourse as a social practice, in Fairclough's view (1995), has three implications: (1) discourse cannot be separated from society, (2) discourse is a social process, and (3) discourse processes according to what is conditioned in society. Social conditions influence discourse and vice versa. Based on these implications, Fauzan, Subroto, \& Poedjosoedarmo (2014), and Fauzan (2015) concluded that linguistic phenomena are having social characteristics, while social phenomena also have linguistic nature.

Linguistics is social because linguistics cannot be completely free from the influence of its social environment. Social conditions are also having linguistic characteristic because language production and re-production activities in a social context are not only manifestations or reflections of social processes and practices, but are also part of the social processes and practices.

CDA characteristics, according to Fairclough (1995), (Zupnik 1991) are also supported van Dijk (1993,1997, 2008), Fairclough and Wodak (1997), Eriyanto (2001), Darma ( 2009) Badara, n.d. (2012), Santoso (2012), Sumarlam (2003, 2013), and Öztürk \& Y1ldırım (2016), consist of action, contexts, history, power, and ideology.

Action. Discourse is understood as an action, socialized as a form of interaction that has a purpose, is expressed consciously, controlled, not something that is out of control or expressed outside of consciousness. Discourse must consider the context of the time and place of the occurrence to past and future events. Participant of the context shows who is involved in the event and its identity (ministers, mass organization figures, people's representatives, etc.), its role in society, power relations owned by the subjects (ministers, mass organization figures, people's representatives, etc.), the adopted ideologies, discourse objectives, and the shared knowledge.

Context. CDA views language as a social practice, so Fairclough (1992) positions the social context as a very important part of CDA, and CDA itself becomes a link between text and the social context. Discourse analysis process considers the context of social situations, social practices, and intertextuality of the process of mutual influence (dialectic) between language and society. Dijk (2008) divides the context into three major groups: settings, participants, and communication events. Participant context shows who is involved in the event and its identity (ministers, mass organization figures, people's representatives, etc.), its role in 
society, their power relations (ministers, mass organization figures, people's representatives, etc.), adopted ideologies, discourse objectives, and shared knowledge.

Historical context. Historical context is important in CDA. When CDA puts discourse in a particular social context, it means that discourse is produced in certain contexts and not understood without including the context surrounding it. CDA does not only find out when the event happened but also wants to know more about why the event happened. The sociopolitical situation, the atmosphere at the time of the event, and other things surrounding the occurrence of the event are important aspects of the historical context.

Power. The context of power is one of the main distinction between discourse analysis and critical discourse analysis. According to Eriyanto (2001), any discourse that appears in the form of text, conversation, or whatever, is not seen as something natural, natural, and neutral, but is a form of power struggle of possessing power (eg. male power over women, king's power over his subordinates, the legislature towards its executives, etc.). Therefore, CDA does not limit itself to the details of the text or the structure of discourse but also relates it to certain social, political, economic, and cultural strengths and conditions. In this case, the dominant group (which has the power) makes it possible for other groups (who do not have the power) to act following what they want. Likewise, the strong ones will control or control the weak group; those in power regulate the controlled, etc.

Ideology. CDA targets hidden ideologies in the use of language. Ideology is a central study in CDA. Eriyanto (2001) says that text, conversation, and others are forms of ideological practices or reflections of certain ideologies. According to Badara, n.d. (2012), ideology has two contradictory notions, positively and negatively. Positively, ideology is as a worldview that states the value of certain social groups to defend and develop their interests. Negatively, ideology is as a false awareness, namely the need to commit fraud by distorting people's understanding of social reality. Discourse is not understood as something neutral and takes place naturally because, at every discourse, there is always an ideology to dominate and seize influence.

From the above explanation, CDA is not only based on a single approach but is always multidisciplinary. CDA seeks to uncover ideologies based on a strategy of positive selfportrayals and negative portrayals of others. Furthermore, this CDA will focus on three analyzes, namely text analysis (description), analysis of discourse practice (interpretation), and analysis of socio-cultural practices (explanations). The three analyzes are presented as follows. 


\section{Text Analysis (Description)}

Analysis at the level of text description focuses more on the use of language to track themes portrayed in the news that reflect ideology. The use of the language includes the use of words, metaphors, and sentence structures used by text producers.

\section{Discourse Practice Analysis (Interpretation)}

Analysis of the practice of discourse (interpretation process) is performed by looking for the meaning of the relationship between text interpretation and context interpretation. Text interpretation is carried out in four levels: utterance, speech meaning, local coherence, and the integrity of the discourse. At the level of utterance, the researchers identify the use of words and sentences using phonological and grammatical knowledge. At the level of utterance meaning (the meaning of utterance), researchers identify speech using semantic and pragmatic knowledge. At the local coherence level, the researchers identify the interconnections between words and sentences by using an understanding of the use of cohesion. Furthermore, at the level of discourse integrity, researchers identify text globally using a scheme.

The context of interpretation is carried out at two levels: the context of the situation and intertextuality. At the context of the situation, the researchers identify the context of the situation by observing the social influence of the text. At the level of intertextuality, researchers investigated the intertextuality of text by comparing existing texts with the previous texts.

\section{Analysis of Socio-Cultural Practices (Explanation)}

Analysis of socio-cultural practices (explanations) is an analysis of the relationship between discourse practice and social context. This analysis aims to find an explanation of the results of interpretation at the level of description and level of interpretation. At this level, researchers analyze and explain $\mathrm{n}$ the relationship between tendencies in the text, complexity in the practice of discourse, and also the processes in social change.

At this stage, the researchers look for an explanation of the results of the interpretation by referring to the socio-cultural conditions around the text produced. Socio-cultural conditions, according to Fairclough (1995), are divided into three parts: situational, institutional, and social. Situational is a unique situation when a text is created. Institutional is the influence of organizational institutions on the text produced. Social is macro things in society, such as political systems, economic systems, or people's culture. 


\section{METHOD}

The CDA framework developed by Fairclough (1995) is three-dimensional (three levels) consisting of text analysis, analysis of discourse practices, and analysis of socio-cultural practices. Text analysis includes three functions, representation functions, relationships, and identities. Analysis of discourse practices related to how to produce and consume text. The socio-cultural practice analyzes three things, namely economics, politics (especially concerning issues of power and ideology), and culture (especially about values and identity) which also influences media institutions and their discourse. The discussion of socio-cultural practices includes three levels, namely, situational, institutional, and social levels. Situational levels are related to production and the context of the situation. The institutional level is related to the influence of institutions internally and externally. The social level is related to more macro situations, such as the political system, economic system, and the cultural system of society as a whole.

The developed methods include (1) linguistic description of the text in terms of language, (2) interpretation of the relationship between the process of production and consumption of text and text (interpretation of inter-textuality relationships), and (3) explanation of the relationship between textual production and consumption and socio-cultural process. Thus, Fairclough's analysis is based on how to connect micro-text to the macro context of society (Fairclough 2005).

\section{RESULTS AND DISCUSSIONS}

In this section, news text analysis is related to the inclusion of IF allowed on the ID card (E-KTP) and other related parties, such as ministers, community leaders, NGO leaders, people's representatives, and political experts, sociologists, and law experts. The elaboration begins with a description of the structure of the news text, the theme of the news text, the grammar of the news text, then followed by an interpretation, and followed by an explanation.

\section{Description of News Text Structure}

Analysis of the structure of the news text is related to the structure of rhetoric used by the involvement of discourse in communication events which generally uses a structured pattern of rhetoric, beginning with orientation, followed by the sequence of events, then ending with a closing; or briefly the news rhetoric consists of the opening, contents, and closing sections (Sumarlam, 2013, 2015). So, the structure of the rhetoric displays the pattern of the preparation of the text presented in the preparation of the opening, core, and closing sections, and provides clues to the intention of a produced text. 
This study shows that the structure of the news text regarding ministers, mass organization leaders, people's representatives, consists of four units of discourse, namely news titles, orientations, sequence of events, and conclusions. The following is one example of news text (4) on antaranews.com., (09/05/2018) entitled "MUI tolak kolom aliran kepercayaan dalam KTP" (Trans: MUI rejects the inclusion of IF allowed on ID card). The construction of text built by the four units of discourse has a different function and forms a unified type of text, namely the news text.

The first unit, the title, the functions are to show the occurred important events. This section determines whether an event is worthy of being news. News text must present interesting, important, and phenomenal information. The more controversial the news, the more appropriate or interesting to expose.

The second unit, orientation, is the part that introduces the core of the reported event. In this case, the core of the event is the policy of the Ministry of Home Affairs to issue e-KTP by allowing the religion column to be filled with 'Penghayat Kepercayaan.' That was according to the order of the Constitutional Court. It took 41 years so that there would be no discrimination for the followers of IF (02/25/2019,news.detik.com).

The third discourse unit, the sequence of events, becomes the most important part of the news text because it is this part that describes in full and details the main occurred events. This section covers the participants of the event, the time and place where the event occurred. This section also contains supporting information sources, such as interviews, quotations from sources, or visual images that support information about the events reported. In the text (4) there is a quote from a national figure Jusuf Kalla who said, "I say once again, the follower of IF can be recorded. Following the government rules "(2/26/2019, jawapos.com). According to JK, the IF people are also Indonesian. Therefore, they continue to obtain civil rights like other Indonesian citizens.

The fourth unit of discourse, the closing, serves to close the transmission of information on occurred events. For example, one of the news texts closes with an appeal, suggestion, or input as follows, Deputy Chairperson of the Indonesian House of Representatives Commission VIII, Sodik Mudjahid, asks the government should be careful and proportional in treating the follower of Indigenous Faiths in various attributes state and government including IF in the ID Card column. It is related to the decision of the Constitutional Court, which decides that IF follower can be included in the ID card (e-KTP). This prudence, according to Sodik, is because the Constitutional Court's decision is only based on the laws and constitutions that apply in the Republic of Indonesia, not based on the faith-based study, 
sharia, and religious law. With the basics of MK's study, added Sodik, the position of IF is not a religion and is not at the level of religion. "Therefore, the religious community is expected to calm down and react wisely" (9/11/2017, Okezone.com).

\section{News Text Theme}

From the search results in the media (internet), ten news texts found in 7 sources of Media Online related to the inclusion of IF in ID card (E-KTP). The news texts proposed the main theme of the inclusion of IF in ID card (E-KTP) as follows: (1) Penghayat Kepercayaan Masuk Kolom KTP, DPR: Umat Beragama Harap Tenang dan Bijak (Trans: IF followers include at ID card Column, people's Representative member: Religious Believers should react peacefully and wisely). (09/11/2017, news.okezone.com), (2) menunggu 41 Tahun, Akhirnya Penghayat Masuk Kolom Agama di KTP (Trans: Waiting for 41 Years, Finally IF followers included at Religious Column on ID Card). (25/02/2019, news.detik.com), (3) Soal Kolom Penghayat Kepercayaan di E-KTP, JK: Mereka Juga Orang Indonesia Trans: (Dealing with The inclusion of IF inclusion at Religous column at E-KTP, JK, They belongs to Indonesian) (26/02/2019, newsokezone.com), (4) MK: Penghayat kepercayaan masuk kolom agama di KTP dan KK (Trans: Constitutional Court: IF may include at religious column on ID Card and Family card). (7/11/2017, bbc.com), (5) Putusan MK Membuat Eksistensi Penghayat Kepercayaan Diakui Negara (Trans: Constitutional Court Decision Makes the Existence of the IF followers Recognized by the State). (07/11/2017, Kompas.com), (6) Muhammadiyah Dukung Putusan MK Terkait Kolom Agama di E-KTP, (Trans: Muhammadiyah Supports Constitutional Court Decisions Regarding the inclusion of IF at Religion Column on E-KTP). ( 07 Nov 2017,Republika.co.id), (7) Ketua MUI Tak Setuju Penghayat Kepercayaan Tercantum di KTP (Trans The Chairperson of the MUI Disagrees with the IF included on the ID card). ( 15/11/2017,cnnindonesia.com), (8) MUI Tegas Tolak Putusan MK Soal Penghayat Kepercayaan. (Trans: MUI Firmly Refuses Constitutional Court decision Regarding IF case). (16/11/2017, republika.co.id), (9) MUI Minta Penghayat Kepercayaan di KTP Tak Dicantumkan di Kolom Agama (Trans: MUI Asks IF Not be Included in the Religious Column on ID Card) (17/01/2018, newsdetik.com) and (10) Tolak Penghayat Kepercayaan Masuk Kolom Agama KTP, Ini Solusi MUI (Trans: Rejecting IF included at the Religious Identity Column at ID Card, This is MUI's solution). (17/01/2018, kiblat.net). 


\section{News Text Grammar}

The grammar in the analysis of news texts is focused on modalities, positive, and negative sentences used in news texts produced both by the media and participants or involved in discourse. The description is as follows.

\section{Modality.}

Modality, according to (Perkins, 1983), is not only the attitude of the speaker to the proposition but also the attitude of the speaker towards events. Modality is the assessment or attitude of the speaker, likes or dislikes, rejects or accepts, agrees or disagrees or may be neutral, which contains the ideology or ideas of the speaker. This shows the position in which the speaker takes sides. Referring to the research of (Alwi, 1992) (Halliday et al., 2014), modalities that also show the attitude and establishment of text producers can be classified into four subcategories, namely intentional modalities, epistemic modalities, deontic modalities, and dynamic modalities. Among the ten observed news texts, four sub-categories of modalities can be stated as follows.

Intentional modality related to the meaning of 'desire, hope, invitation, request' within the text:

1) Tahun 1965: Lahir Penetapan Presiden (yang nantinya menjadi UU PNPS 1/1965 tentang Penodaan Agama) yang ingin melindungi agama dari penodaan oleh aliran kepercayaan. Trans: In 1965: The Presidential Decree was issued (which would later become the PNPS 1/1965 Law on Blasphemy of Religion) who wanted to protect religion from blasphemy by the IF communities. (25/02/2019, news.detik.com).

From this quotation, it shows that the intentional modality linguistic marker of "ingin" or "wanted" in the release of a presidential decree in 1965 which later on called as Law on Blasphemy of Religion. It is a decree that aims to protect religion from the blasphemy by a group of IF.

2) Dengan basis-basis kajian MK tersebut, tambah Sodik, maka posisi aliran kepercayaan atau penghayat kepada Tuhan yang Maha Esa adalah bukan agama dan tidak setingkat dengan agama. "Karena itu kepada umat beragama diharapkan tenang dan menyikapinya dengan bijak. Trans: With the basis of the Constitutional Court's study, added Sodik, the position of the creed or followers of the IF is not a religion and is not at the level of religion. "Therefore, the religious community is expected to calm down and react wisely (11/09/2017, okezone.com).

From this quotation, it shows the intentional modality linguistic marker of "diharapkan" or "is expected to" in the statement of Sodiq who said that by the basis of constitutional court's decision, the follower of IF should calm down and react wisely. 
Epistemic modality related to knowledge and beliefs, which can mean "possibility, necessity, certainty."

1) Meski begitu, politikus Partai Gerindra ini tetap mengapresiasi langkah Menteri Dalam Negeri Tjahjo Kumolo yang akan berkonsultasi dengan Majelis Ulama Indonesia (MUI) untuk menentukan tindak lanjut pasca keluarnya putusan MK itu. Trans: Even so, the Gerindra Party politician still appreciates the steps of Internal affairs Minister Tjahjo Kumolo who will consult with the Indonesian Ulema Council (MUI) to determine the follow-up after the Constitutional Court's decision was issued. (09/11/2017, news.okezone.com)

From this quotation, it can be found the epistemic modality linguistic marker of "akan" or "will" in the statement of Gerindra party politician who appreciates the decision of internal affair minister Tjahjo Kumolo who will consult the decision of Constitutional court to the Indonesian Ulema Council (MUI).

2) Tahun 1978 Lahir TAP MPR Nomor 4/1978 yang menyatakan bahwa kepercayaan bukanlah agama, melainkan kebudayaan. TAP ini juga mengharuskan adanya kolom agama (yang wajib diisi dengan satu di antara 5 agama) dalam formulir pencatatan sipil. Trans: In 1978 the MPR TAP was born Number 4/1978 which stated that Indigenous Faiths is not a religion, but culture. This TAP also requires the existence of a religious column (which must be filled with one in 5 religions) in the civil registration form. $(02 / 25 / 2019$, news.detik.com $)$

From this quotation, it shows that the epistemic modality linguistic marker of "mengharuskan" or "requires" in the People's representative's decree at 1978 which requires the existence of a religious column which must be filled with one of 5 existing religions in the civil registration form.

Deontic modality related to the meaning of 'obligations, permits, orders, prohibitions, warnings':

1) Hal ini terkait dengan putusan Mahkamah Konstitusi (MK) yang memutuskan penganut Penghayat Kepercayaan boleh dicantumkan dalam kolom agama di Kartu Tanda Penduduk (KTP). Trans: This is related to the decision of the Constitutional Court's decision which decides that the Believer of Indigenous Faith may be included in ID Card (KTP). (09/11/2017, news.okezone.com)

From this quotation, it show that the deontic modality linguistic marker of "boleh" or "may be" in constitutional court's decision that the believer of IF may be included in ID Card.

2) Kemendagri mencetak e-KTP dengan membolehkan kolom agama diisi 'Penghayat'.

Trans: The Ministry of Home Affairs prints e-KTP by allowing the religion column to be filled with 'Indigenous Faiths'. (02/25/2019, news.detik.com)

From this quotation, it shows that the deontic modality linguistic marker of "membolehkan" or "allowing" in the ministry of Home affairs who decided to print e-KTP which allowing the religion column to be filled with "Indigenous Faiths." 
Dynamic modalities related to the meaning of 'ability':

1) "Memang aturannya begitu, dia (penghayat kepercayaan) orang Indonesia juga. Kan sudah ada penjelasan juga sebelumnya bahwa aliran kepercayaan itu bisa berdiri sendiri, bisa dicatat. Ya sesuai (aturan) itu," kata Wapres Jusuf Kalla. Trans: "Indeed the rules are like that, he (the IF) of the Indonesian people too. There has also been an explanation beforehand that the believers of IF can stand alone; it can be recorded. Yes, according to the rules," said Vice President Jusuf Kalla. (2/26/2019, Newsokezone.com).

From this quotation, it can be found the dynamic modality linguistic marker of "bisa" or "can" in the statement of Vice President Jusuf Kalla that the believers of IF can stand alone, and this is in accordance to the rules.

2) Kuasa hukum para penggugat, Julianto Simanjuntak, mengapresiasi putusan MK yang membuat para penganut kepercayaan bisa mengisi kepercayaan mereka pada kolom agama di KTP dan KK. Trans: The attorneys of the plaintiffs, Julianto Simanjuntak, appreciated the Constitutional Court's decision to make IF believers able to fill their beliefs in the religious column on the ID Card and Family Card (KK). (11/07/2017, bbc.com)

From this quotation, it can be found the dynamic modality linguistic marker of "bisa" or "able to" in the statement of Julianto Simanjuntak who appreciated the Constitutional Court's decision to make IF believers able to fill the status of their beliefs in the religious column on the ID Card and Family Card (KK).

\section{Ideology, modalities, positive and negative sentences.}

The quoted text of the news provides textual evidence that the use of modality is one vehicle or linguistic proof for building ideology because modalities show subjective or collective attitudes or assessments of the production of news texts on an event. Viewed from the subcategory of modalities (both expressed with positive and negative sentences), it is clear that the use of epistemic modalities dominates the reporting of inclusion of IF on the ID card (E-KTP), which is 7 data (43\%). Meanwhile, the use of the other three modalities, namely intentional modalities (18\%), deontic modalities (25\%), and dynamic modalities (13\%). Epistemic modality represents the attitude of the text producer related to the knowledge and beliefs of a nonfactual proposition and event in the form of 'possibility or practice, and necessity.' That is the occurrence of inclusion of the IF on ID card (E-KTP). It attracts the attention of various parties in such a way that the various parties predict the possibilities that will occur and which should occur after the issuance of the determination of the inclusion of the IF on ID card (E-KTP).

In the analyzed ten news texts, text production consists of two main parties; namely the supporters of the inclusion of IF in ID card (E-KTP). Namely those in government such as Jusuf Kalla, Minister of Religion, Constitutional Court and Party politicians. While religious 
leaders in the MUI strongly refused the inclusion of IF on ID card (E-KTP). The ideology built through the use of modalities and positive or negative sentences by the group as follows.

\section{The supporters of the inclusion of IF in ID card (E-KTP)}

There were three statements or direct quotes from government figures such as Jusuf Kalla, Amrin Tamagola, Sociologist from the University of Indonesia and Muhammadiyah secretary General Abdul Mu'ti who supported the decision to include IF on ID card (E-KTP). One of them is the Jusuf Kalla's statement:

"Memang aturannya begitu, dia (penghayat kepercayaan) orang Indonesia juga. Kan sudah ada penjelasan juga sebelumnya bahwa aliran kepercayaan itu bisa berdiri sendiri, bisa dicatat. Ya sesuai (aturan) itu," kata Wapres Jusuf Kalla . Trans: "Indeed the rules are like that, he (Believer of IF ) belongs to Indonesian people too. There has also been an explanation beforehand that the belief of IF can stand alone, it can be recorded. Yes, according to the rules," said Vice President Jusuf Kalla. (2/26/2019, antaranews.com).

\section{The group that disagrees with the inclusion of Indigenous Faiths}

The group that disagrees with the inclusion of Indigenous Faiths on ID Card (E-KTP) is K.H Ma'ruf Amin, the head of the MUI and Chairperson of the MUI's Law and Legislation, Basri. One of them is K.H Ma'ruf Amin's rejection of the idea of the inclusion of Indigenous Faiths on Identity Card:

Terkait penolakan itu, KH Ma'ruf mengatakan MUI segera menyiapkan langkah menyikapi putusan MK. Namun, ia berujar, MUI belum memutuskan langkah itu. "Pokoknya kita menolak dan meminta supaya itu tak ditindaklanjuti Kemendagri," tutur dia. Trans: Regarding the rejection, KH Ma'ruf said that the MUI immediately prepared steps to respond to the Constitutional Court's decision. However, he said, the MUI had not yet decided on the move. "In essence, we reject and ask that it not be followed up by the Ministry of Home Affairs," he said. (11/16/2017, republika.co.id)

From those statements, the researcher identified discourse productivity produced by each camp. The group supporting the inclusion of Indigenous faiths in the religious column on ID Card (E-KTP) contained six more headlines than the opponents with only four titles. The first group gave more positive appeal so that the Indonesian people respected the judge's decision because we were a rule of law while the Indonesian Ulema Council stated many negativepitched speeches: cornering, blaming, banning, etc.-- These speeches represented the negative ideology of the speaker, namely the second group.

\section{Interpretation}

Interpretation is an analysis of discourse practice, namely the analysis of the relationship between text and discourse practice by looking at the text as a production process. Interpretation is done by utilizing sources of interpretation and various principles of interpretation (Sumarlam, 2013) so that it can produce an accurate interpretation (high level of truth). Besides, researchers can also conduct intertextuality studies (Fairclough, 1992, 1995), 
which are examining the relationship between one news text and other grievous news texts, and the context behind the production of a text. This study is based on ten news texts from several media sources.

Among the ten news titles, six titles have titles with positive values, and the rest are four negative titles. The other four titles, as shown above, are all negative. Further interpretations regarding the inclusion of the belief flow in the religious column on the electronic resident card (E-KTP) can be expressed by looking at the intertextual relations (intertextuality studies) in brief as follows.

After analyzing the news text and interpreting the text intertextuality, then Fairclough (1989) states the analyst concludes to interpret the discourse constructed by the text. Interpretations carried out to include four dimensions: What's going on, who is involved, What relationships are at issue, and the role of language. The results of the interpretation of news texts from various media sources can be presented as follows.

\section{What's going on.}

Inclusion of indigenous faiths in the religious column on ID card (E-KTP) is a very interesting issue because Indonesia is a country that is very easy triggered into racial problems and it is proven that the followers of indigenous faiths often get difficulties in community life in finding jobs, getting married and so on and it took 41 years for followers of indigenous faiths to succeed in getting a Supreme Court decision related to the inclusion of indigenous faiths in the religious column on ID card (E-KTP).

\section{Who's involved.}

The government, politicians, and members of the Board as supporters and the Indonesian Ulema Council as opponents in connection with the inclusion of Indigenous faiths in the religious column on ID Card (E-KTP) as the text producer want to display their positive image and opinion among the people in their way.

\section{What relationships are at issue?}

Media (print and electronic), following their functions, always provide information and present interesting news. Among the interesting news are controversial issues. The more controversial the news is, the more interesting. The inclusion of indigenous faiths on the ID card (E-KTP) is one of the issues that attract the attention of the Indonesian people.

\section{The role of language.}

The use of language (text structure, sentence structure, vocabulary selection) in the news text greatly determines the attitudes and opinions of the consumers (readers or viewers). If someone (certain party) is reported negatively continuously and repeatedly, then the audience 
will believe and participate in evaluating negatively towards that person/party. Conversely, if someone (certain party) is reported positively (repeatedly) and continually (continuously for quite a long time), then that person will be positive as well as his image in the view of the audience. This case is the power of language that is utilized by the involvement of discourse and media in building images. Proponents of inclusion Of Indigenous Faiths in the religious column on ID cards (E-KTP) produce positive news texts for themselves and tend to build negative news texts for people who disagree with them.

\section{Explanation}

The explanation is an analysis of the relationship between the practice of discourse and the social context (analysis of socio-cultural practices). Explanation aims to find an explanation of the results of the interpretation in the description and interpretation stages. At this level, the researchers explain the relationship between tendencies in the text, the complexity in the practice of discourse, and the process in social change.

Besides, the researchers also explained the results of the interpretation by referring to socio-cultural conditions which consisted of three important parts, namely Situational that is the situation when a text is produced. Institutional, namely the influence of organizational institutions on the text produced. Namely observing macro things in the community related to economic, political, social, and cultural interests in Indonesia.

The explanation of the explanatory results related to this study is as follows.

\section{The process of changing the situation}

The process of changing the historical situation is related to the attitude of the religious community towards indigenous faiths Followers in Indonesia, as quoted from the information from the Center for Religious and Cross-Cultural Studies (CRCS) expert at Gadjah Mada University (UGM), Samsul Maarif, presented at Constitutional Court's Trial:

During the Old Order, the word "Religion" was defined very exclusively, namely those who possessed the holy book, the prophet, and international recognition. This definition determines who is served (adherents of 'official' religion) and who is not served (indigenous faiths). In 1953, the Old Order Government formed Pengawas Aliran Kepercayaan. The Ministry of Religion reported that there were 360 indigenous faiths organizations. Included in Badan Koordinasi Kebatinan Indonesia (BKKI). In 1955, the BKKI held a congress with the chairman of Mr. Wongsonegoro, one of the formators of the 1945 Constitution. In 1965, the Presidential Decree was declared (later on become the PNPS 1/1965 Law on Blasphemy of Religion) who wanted to protect religion from blasphemy by the cult. After the events of 
September 30, 1965, the indigenous faiths were under great pressure: they were suspected of being part of communism.

In 1970, the fate of the trustees had improved when Golkar formed the Sekretariat Kerja Sama Kepercayaan (SKK). SKK then transformed into the Badan Kongres Kepercayaan Kejiwaan Kerohanian Kebatinan Indonesia (BK5I). In 1973, the MPR resolution was issued on GBHN which stated religion and Indigenous Faiths were expressions of belief in God who were both 'legitimate', and both 'equal'. In 1978, it was issued MPR decree No. 4/1978 which stated that Indigenous Faiths is not a religion, but culture. This decree also requires the existence of a religious column (which must be filled with one among five religions) in the civil registration form. This moment has the deepest impact on the bad fate of the believing community.

In the Reformation era with the inclusion of human rights clauses in state legal instruments, believers again gained recognition. With human rights instruments, believers are protected from coercion to "official" religion. In 2006, the Population Administration Law was revised but still discriminated against the belief groups, namely by the existence of Article 61 of the 2006 Adminduk Law: Indigenous Faith's identity was not recorded in the religion column. In 2016, four belief groups, namely Nggay Mehang Tana, Pagar Demanra Sirait, Arnol Purba, and Carlim, sued Article 61 paragraph 1 and 2 of the Law on Population Administration to the Constitutional Court. The article reads: Information on the religious column as referred to in paragraph (1) for Residents whose religion has not been recognized as a religion by the provisions of the Laws or Indigenous Faiths is not filled in ID Card, but is still served and recorded in the Population database.

On 3rd May 2017, the Constitutional Court held the final verification session and on 7th November 2017, the Constitutional Court granted the lawsuit of the residents of the Indigenous Faiths group. The Constitutional Court granted the claim because the Indigenous Faiths received different treatment with the followers of the existing religion recognized in Indonesia. "Restrictions on quo rights lead to the emergence of unfair treatment of citizens of belief groups as argued by the Petitioners.

By not fulfilling the reasons for limiting rights as set out in Article 28J paragraph (2) of the 1945 Constitution, restrictions based on beliefs have implications treatment differently between citizens is discriminatory, "said Chief Justice of the Constitutional Court, Arief Hidayat. In 2019, the Directorate General of Civil and Civil Engineering printed an e-KTP with a religious column filled with ' Indigenous Faiths' following the Constitutional mandate.

\section{The process of institutional change}


Many parties feel concerned to take part in the case of the inclusion of indigenous faiths in the religious column on the ID card (E-KTP). In addition to those involved as direct perpetrators of religious beliefs and the Indonesian Ulema Council, the government and political, sociological, and legal experts also felt the need to intervene as evidence of their concern for solving the sensitive problem. Besides, media institutions (print and electronic, local and national) are also interested in presenting the latest news and information in building public opinion related to the inclusion of Indigenous Faiths in the religious column on the ID card (E-KTP). What is the attitude of the government and religious community towards followers of Indigenous Faiths followers after the Constitutional Court's decision becomes an actual and factual question that needs to be found immediately.

\section{Process of social change}

University of Indonesia sociologist Thamrin Amal Tomagola appreciates the decision of the Constitutional Court to grant a request for judicial review regarding the rules for emptying religious columns on family cards and identity cards. Through this Constitutional Court decree, the existence of indigenous faiths followers is recognized by the state. $(11 / 07 / 2017$, kompas.com). According to Thamrin, there is no word "recognition" in the Population Administration Act. There is no provision in the law which states that the state recognizes six religions in Indonesia. Recognition of six religions is only a statement in one verse. So, then people fool others, fool the public that as if only six religions were recognized by law. According to Thamrin, there will be social changes in the community after the existence of the state's recognized belief groups. The change was mainly about the status and civil rights of citizens of the belief groups. Trustees are recognized by the state and then they make ID cards. So far they do not have a KTP so they cannot take care of a health card such as BPJS. The support for the government and NKRI is likely to increase after the recognition of the civil rights of the citizens of the Indigenous Faiths group.

\section{CONCLUSION}

This study was conducted to reveal the power representation that was built by the religious community, the government officials and experts on news texts in several media regarding the inclusion of Indigenous Faiths in the religious column on E-KTP using the Fairclough CDA model (Fairclough, 1995). This study produces the following conclusions.

The structure of the news text regarding the inclusion of the indigenous faiths on the ID card (E-KTP) consists of four units of discourse, namely the headline, orientation, sequence of events, and closing. The use of modalities in the news text studied is dominated by epistemic 
modalities compared to the other three modalities, namely intentional, deontic, and dynamic modalities. Epistemic modalities represent participant attitudes to propositions and events concerning possibilities or predictions in the form of predictions and fate and the future that will occur in Indonesia post-inclusion of Indigenous Faiths on ID cards (E-KTP), and those should be done or not done by the stakeholders involved in the discourse. The use of these modalities in positive or negative sentences represents a particular ideology. The news text of the inclusion of the indigenous faiths on the ID card (E-KTP) that has been described needs to be interpreted inter-textually to reach a more comprehensive conclusion. Interpretation includes four dimensions: what happens, who is involved, what is the relationship with the issue raised, and what is the role the language in the event. Explanation aims to explain the results of the interpretation at the stage of description and interpretation. In this case, the analyst explains the results of the interpretation by referring to socio-cultural conditions which consist of three important parts, namely (a) the situation when the news text regarding the inclusion of an indigenous faiths in ID card (E-KTP) is produced, (b) the influence of organizational institutions on the text produced, and (c) macro matters in Indonesian society related to economic, political, social and cultural interests.

\section{REFERENCES}

Alwi, H. (1992). Modalitas dalam bahasa Indonesia. Penerbit Kanisius.

Badara, A. (2012). Analisis wacana: Teori, metode, dan penerapannya pada wacana media. Jakarta: Kencana Prenada Media Group.

Darma, Y.A. (2009). Analisis wacana kritis. Bandung: Yrama Widya.

Eriyanto. (2001). Analisis wacana: Pengantar analisis Teks media. Yogyakarta: LKiS.

Dijk, T. A. van. (2008). Discourse and power. Retrieved from https://books.google.co.id/books/about/Discourse_and_Power.html?id=NhILAQAAMA AJ\&redir_esc=y

Fairclough, N. (1992). Intertextuality in critical discourse analysis. Linguistics and Education. https://doi.org/10.1016/0898-5898(92)90004-G

Fairclough, N. (1995). Critical discourse analysis: The critical study of language. In Longman Group Limited. https://doi.org/10.2307/329335

Fairclough, N. (2005). Discourse analysis in organization studies: The case for critical realism. Organization Studies. https://doi.org/10.1177/0170840605054610

Fauzan, U. (2015). Analisis wacana kritis teks berita Metrotv dan Tvone mengenai "Luapan lumpur sidoarjo." Retrieved from https://digilib.uns.ac.id/dokumen/detail/44233/Analisis-wacana-kritis-teks-beritametrotv-dan-tvone-mengenai-Luapan-Lumpur-Sidoarjo

Fauzan, U., Subroto, H. D. E., \& Poedjosoedarmo, S. (2014). A CDA of the ideology of Indonesian Metrotv news report. International Journal of Linguistics, 6(4), 71. https://doi.org/10.5296/ijl.v6i4.6147 
Halliday, M. A. K. \& Matthiessen, C. M. I. M. (2014). An Introduction to Functional Grammar. https://doi.org/10.4324/9780203783771

Öztürk, M., \& Yıldırım, A. (2016). English as a foreign language instructors' cognitions on language learning processes and factors affecting those cognitions. TED EĞITIM VE BILIM, 4O(182). https://doi.org/10.15390/EB.2015.4776

Sumarlam, (2003). Teori dan praktik analisis wacana. Pustaka Cakra.

Perkins, M. R (1983).Modal expressions in English. Noorwood: Ablex Publishing Corporation.

Rani, A. (2005). Penggunaan bahasa pada wacana iklan televisi (Doctoral Thesis). Program Pascasarjana, Universitas Negeri Malang.

Santoso, A. (2012). Studi bahasa kritis: Menguak bahasa membongkar kuasa. Bandung: Penerbit Mandar Maju.

Sumarlam. (2013). Teori dan praktik analisis wacana. Surakarta: bukuKatta.

Zupnik, J. Y. (1991). Norman fairclough, language and power. London: Longman. 1989 Pp. x + 248. Language in Society, 20(2), 265-269. https://doi.org/10.1017/S0047404500016316 